кафедры административного менеджмента и альтернативных источников энергии, Винницкий национальный аграрный университет (21008, г.Винница, ул.Солнечная, 3, e-mail: tokarchyk_dina@ukr.net).

УДК: 65.015.13

DOI: $10.37128 / 2411-4413-2020-2-7$

\section{АУТСОРСИНГ У СИСТЕМІ УПРАВЛІННЯ ПІДПРИЕМСТВОМ}

\author{
ДАНИЛЮК Т. І., \\ кандидат економічних наук, доцент \\ кафедри економіки, безпеки \\ та інноваційної діяльності підприємства,
}

МОХНЮК А. М., кандидат економічних наук, доцент кафедри економіки, безпеки та інноваційної діяльності підприсмства, Східноєвропейський національний університет ім. Лесі Украӥнки (м. Луцьк)

Ведення бізнесу в умовах конкурениії випливає з того, щзо ефективне використання ресурсів підприємства неможливе без адекватних змін у сфері управління бізнесом та урахувань зв'язків, які визначають нові тенденції в управлінні підприємствами. У цій ситуачії знаходять гідне місие високі технології управління, серед яких аутсорсинг.

Аутсорсинг важливий при зниженні витрат, скороченні часу виконання, збільшенні прибутку, підвищенні конкурентоздатності, укладанні договорів, ділових відносинах тощо. Приділення значної уваги аутсорсингу в управлінській діяльності є актуальною проблемою сьогодення. Варто визначити важливість аутсорсингу в стратегічній діяльності підприємства та виділити взаємозв'язок управлінських функиій із конкретними видами аутсорсингових послуг, чим і обтрунтовується актуальність иієєї теми.

У статті розглянуто категорію аутсорсингу як однин з основних факторів ведення сучасного бізнесу для підвищення ефективності бізнес-проиесів. Наведено твердження науковиів про аутсорсинг як про ефективну стратегію управління бізнесом та дієвий інструмент управління діяльністю підприємства. Досліджено вагомість аутсорсингу бізнеспроцесів у сфері управлінського бізнесу. Вивчено напрями визначення поняття "аутсорсинг» y межах управлінського підходу щзодо розкриття його сутнісного розуміння. Виділено аутсорсинг основних і допоміжних функиій із розподілом бізнес-проиесів на підприємстві.

Розглянуто види аутсорсингу, залежно від бізнес-процесів у складі кожної функиіі управління: планування, організування, мотивування, контролювання, регулювання. Показано взаємозв'язок функиій системи управління підприємством із видами аутсорсингу та видами бізнес-прочесів підприємства. Виділено основні прочеси, щзо планує удосконалити підприсмство в результаті їх передачі на аутсорсинг. 3'ясовано важливість аутсорсингу бізнес-прочесів як частини антикризової програми підприсмства. 
Ключові слова: аутсорсинг, аутсорсинг бізнес-процесів, аутсорсинг у межах управлінського підходу, аутсорсинг основних функцій, аутсорсинг допоміжних функцій, види аутсорсингу у складі функцій управління.

Рис.: 2. Літ.: 11.

\title{
OUTSOURCING IN THE ENTERPRISE MANAGEMENT SYSTEM
}

\author{
DANYLIUK Tetiana, \\ PhD in Economics, Associate Professor, \\ Department of Economics, Security and Innovation of the Enterprise,
} MOKHNIUK Anna, PhD in Economics, Associate Professor, Department of Economics, Security and Innovation of the Enterprise, Lesya Ukrainka Eastern European National University (Lutsk) Doing business in a competitive environment is based on the fact that the efficient use of
enterprise resources is impossible without making relevant changes in the field of business
management as well as taking into consideration the links that determine new trends in enterprise
management. In this situation high management technologies such as outsourcing take a pride of
place.
Outsourcing is important in reducing costs, decreasing operation time, increasing profits,
enhancing competitiveness, signing up contracts, improving business relationships and etc. Paying
significant attention to outsourcing in business management is an urgent problem nowadays. It is
necessary to determine the importance of outsourcing in the strategic activities of the enterprise and
highlight the correlation among management functions and certain types of outsourcing services.
This confirms the significance and the necessity of studying this question.
A category of outsourcing as one of the most effective management tools for increasing the
efficiency of business processes is considered in this article. The scientists' statements about
outsourcing as successful business management strategy as well as an efficient tool for managing the
activities of the enterprise are presented. The importance of business processes outsourcing in the
field of business management is investigated. The directions of defining the concept of
"outsourcing" within the framework of the management approach considering the representation of
understanding its nature are studied. The outsourcing of basic and auxiliary functions with the
distribution of business processes at the enterprise is distinguished.
Types of outsourcing according to business processes within each management function such
as planning, organization, motivation, control and regulation are considered. The relationship
among the functions of the enterprise management system, the types of outsourcing and the types of
enterprise business processes is demonstrated. The main processes that the company plans to improve
as a result of their outsourcing are highlighted. The significance of business processes outsourcing
as a part of the company's crisis program is clarified.

Keywords: outsourcing, business processes outsourcing, outsourcing within the management approach, outsourcing of basic functions, outsourcing of auxiliary functions, types of outsourcing within management functions.

Fig.: 2. Ref.: 11.

\section{АУТСОРСИНГ В СИСТЕМЕ УПРАВЛЕНИЯ ПРЕДПРИЯТИЕМ}


ДАНИЛЮК Т. И., кандидат экономических наук, доцент кафедры экономики, безопасности и инновационной деятельности предприятия,

\author{
МОХНЮК А. М., \\ кандидат экономических наук, \\ доцент кафедры экономики, безопасности \\ и инновационной деятельности предприятия, \\ Восточноевропейский национальный \\ университет им. Леси Украинский
}

Ведение бизнеса в условиях конкуренции следует из того, что эффрективное использование ресурсов предприятия невозможно без адекватных изменений в сфере управления бизнесом и учетов связей, которые определяют новые тенденции в управлении предприятиями. В этой ситуации находят достойное место высокие технологии управления, среди которых аутсорсинг.

Аутсорсинг важен при снижении расходов, сокращении времени выполнения, увеличении прибыли, повышении конкурентоспособности, заключении договоров, деловых отношениях и тому подобное. Обращение внимания на аутсорсинг в управленческой деятельности является актуальной проблемой современности. Следует определить важность аутсорсинга в стратегической деятельности предприятия и выделить взаимосвязь управленческих функиий с конкретными видами аутсорсинговых услуг, чем и обосновывается актуальность данной темьл.

В статье рассмотрена категория аутсорсинга, как одна из самых действенных инструментов управления для повышения эффективности бизнес-процессов. Приведены утверждение ученых об аутсорсинге как об эффективной стратегии управления бизнесом и действенным инструментом управления деятельностью предприятия. Исследована значимость аутсорсинга бизнес-прочессов в сфере управленческого бизнеса. Изучень направления определения понятия «аутсорсинг» в рамках управленческого подхода $к$ раскрытию его сущностного понимания. Выделено аутсорсинг основных и вспомогательных функиий по распределению бизнес-процессов на предприятии.

Рассмотрены виды аутсорсинга, в зависимости от бизнес-процессов в составе каждой функиии управления: планирование, организации, мотивации, контроля, регулирования. Показана взаимосвязь функиий системы управления предприятием с видами аутсорсинга и видами бизнес-процессов предприятия. Выделены основные процессы, которые усовершенствует деятельность предприятия в результате их передачи на аутсорсинг. Выяснено важность аутсорсинга бизнес-прочессов как части антикризисной программы предприятия.

Ключевые слова: аутсорсинг, аутсорсинг бизнес-процессов, аутсорсинг в рамках управленческого подхода, аутсорсинг основных функций, аутсорсинг вспомогательных функций, виды аутсорсинга в составе функций управления.

Рис.: 2. Лит.: 11.

Постановка проблеми. У сучасних умовах господарювання керівництво підприємств змушене удосконалювати управлінські технології для оптимізації їхньої діяльності, скорочувати неефективні бізнес-процеси та застосовувати 
гнучкість управління бізнесом. Одним із найбільш впливових інструментів управління, що дає можливість підприємству посилити конкурентні переваги на основі підвищення ефективності бізнес-процесів, $\epsilon$ аутсорсинг. Відтак, приділення значної уваги аутсорсингу в управлінській діяльності є актуальною проблемою сьогодні, вирішення якої полегшить процес організації взаємовідносин під час здійснення аутсорсингової діяльності.

Аналіз останніх досліджень і публікацій. Аутсорсинг у сучасних умовах ведення бізнесу виділяється як один із визначальних чинників оптимізації управлінської діяльності та один із дієвих шляхів підвищення гнучкості управління.

Істотний внесок у вивчення поняття «аутсорсинг» у системі управління підприємством зробили сучасні зарубіжні науковці. Ронан Мак Івор [1, с.24] визначає аутсорсинг як стратегічне управлінське рішення, яке приймається найчастіше для довгострокової конкурентоспроможності організації і поєднує цей термін із «ключовою компетенцією». Джеспер Моммеа та Ганс-Генрік Хволбиб [2, с.187] ураховують підхід до процесу стратегічного планування i визначають аутсорсинг складовою частиною стратегії.

Про аутсорсинг як дієвий інструмент управління діяльністю підприємства говорять у своєму дослідженні Тропіцина Ю. [3, с.253], Тонюк М. [4, с.374] та Попова А. [5, с.160]. Бабій М. розглядає аутсорсинг як загальну концепцію управління бізнесом [6, с.55]. Висоцький В. досліджує поняття аутсорсинг, виходячи 3 позицій управління суб'єктом господарювання, підкреслюючи одну 3 ознак такого управління, що дозволяє досягти ефективного застосування аутсорсингу [7, с.63]. Важливість застосування аутсорсингу в стратегічній діяльності підприємства розглядають і наші українські вчені Сухоняк С. [8, с.77] та Лабжанія Р. [9, с.358], де визначають аутсорсинг як комплексне стратегічне рішення для здійснення ефективного управління.

Варто зазначити, що всі дослідження пов'язані 3 упровадженням аутсорсингу в стратегічну діяльність підприємства виділяються без особливого взаємозв'язку управлінських функцій із конкретними видами аутсорсингових послуг, чим і обгрунтовується актуальність та вибір даної теми.

Формулювання цілей статті. Цілями наукового дослідження $\epsilon$ обгрунтування доцільності застосування аутсорсингу в управлінській діяльності підприємств із визначенням бізнес-процесів відповідно до функцій управління та викладення авторського бачення шляхів активізації цього процесу в управлінську діяльність підприємства.

Виклад основного матеріалу дослідження. У галузі управління в наш час домінує процесний підхід орієнтації на клієнта, тобто споживача продукції. У зв'язку з цим процеси розглядаються як потоки робіт, а в системі управління вони отримали назву бізнес-процесів, які створюють результат (продукт, послугу), що має цінність для споживача [5, с.161].

Цифрові інновації призводять до серйозної перебудови багатьох бізнеспроцесів, і це дозволяє під новим кутом подивитися на модель управління 
компанією. У Східній Європі та Україні все більше набирає обертів модель управління бізнесом під назвою ВРО (англ. Business process outsourcing) [10]. Для багатьох підприємств аутсорсинг давно $є$ незмінною частиною бізнес-стратегії.

Передача функцій або бізнес-процесів від одного суб'єкта господарювання іншому передбачає взаємодію таких суб'єктів господарювання між собою. Це і визначає розгляд аутсорсингу у межах управлінського підходу, бо досягнення конкурентоспроможності, стратегічного розвитку, оптимізації різновидів діяльності неможливе без врахування взаємодії між різними економічними суб'єктами [11]. На підставі зазначеного Васильченко Г. В. визначає аутсорсинг у межах управлінського підходу (рис. 1):

- виходячи із загальної концепції ефективного управління підприємством (стратегія, концепція, технологія);

- на основі підкреслення однієї зі складових в управлінні діяльністю підприємства (досягнення конкурентоспроможності, мінімізація втрат, отримання прибутку);

- на підставі розгляду аутсорсингу в якості деякого інструментарію управління підприємством (метод, спосіб, технологія, інструмент).

Такі визначення аутсорсингу є досить вдалими, оскільки визначають коло проблем, що розв'язуються у процесі управлінської діяльності та зводяться до визначення конкретних цілей розвитку, використовуючи дієві інструменти управління. Використання аутсорсингу в управлінській діяльності підприємства дозволяє успішно розвиватися, покращувати результати діяльності та підвищувати рентабельність бізнесу. На цій основі виділяються бізнес-процеси, що потребують залучення зовнішніх контрагентів, котрі спеціалізуються на виконанні певних, як правило, непрофільних для підприємства адміністративногосподарських функцій.

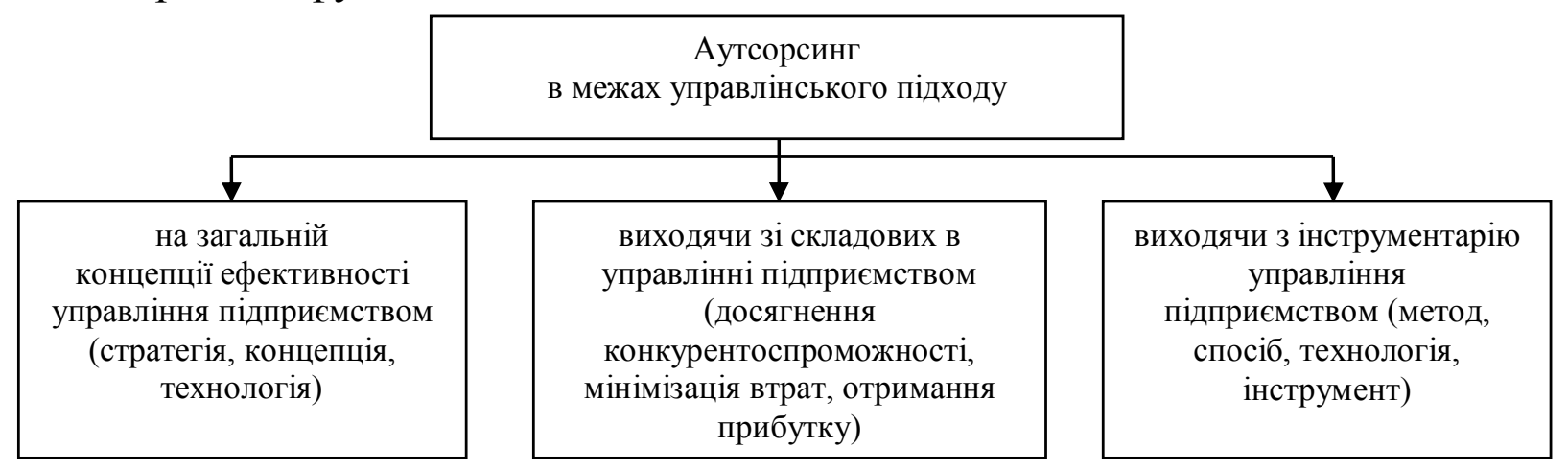

Рuc. 1. Напрями визначення поняття «аутсорсинг» у межах управлінського підходу щодо розкриття його сутнісного розуміння Джерело: побудовано на основі [11]

Відповідно до визначених на підприємстві бізнес-процесів, можна виділити аутсорсинг основних функцій і допоміжних функцій. До аутсорсингу допоміжних функцій відносять бізнес-процеси, які не мають прямого впливу на формування та обсяг виручки підприємства, це такі як охоронні послуги, послуги 
прибирання, юридичні послуги. Бізнес-процеси, які безпосередньо впливають на виручку підприємства потрібно розглядати як аутсорсинг основних функцій. До них передусім належать виробничі, логістичні та заготівельні бізнес-процеси на підприємстві.

Кожна функція управління може бути спрямована на передачу певних іiі бізнес-процесів для вирішення специфічних, різноманітних і складних проблем взаємодії між суб'єктом господарювання та окремими підрозділами підприємства, тобто на аутсорсинг. Із метою закріплення окремих видів робіт за виконавцями і тим самим упорядкування процесу управління розглянемо види аутсорсингу, залежно від бізнес-процесів у складі кожної функції управління: планування, організування, мотивування, контролювання, регулювання.

Функція планування в системі управління $є$ першочерговою і дозволяє керівництву підприємства формулювати місію, мету, цілі та завдання діяльності, аналізувати зовнішнє відносно організації середовище, проводити управлінське обстеження сильних і слабких сторін, розробляти стратегію діяльності, складати програми розвитку і плани досягнення поставлених завдань. Реалізація функції планування полягає у вивченні і застосуванні принципів, методів та програм вдосконалення діяльності підприємства, що полягає у виявленні можливостей, факторів, загроз і умов як на стратегічному, тактичному та і оперативному рівнях. Тобто планування як функція управління виконує не тільки оперативні завдання, але і завдання перспективного розвитку.

Прийняття рішення про перехід на аутсорсинг є складне комплексне завдання, що належить до стратегічної діяльності компанії. Різновиди робіт для передачі на аутсорсинг залежать від наявності на підприємстві видів і служб, які забезпечують їх виконання. Тому, в системі планування діяльності ряд бізнеспроцесів можна передати аутсорсеру для виконання: логістика, IT-консалтинг, маркетинг, бухгалтерський облік та фінанси, розрахунок заробітних плат, CRMаутсорсинг. Передаючи аутсорсеру дані бізнес-процеси, підприємство планує знизити ризик, мінімізувати витрати, швидко реагувати на зміни середовища, досягти фінансової стійкості, оптимізувати ресурси підприємства, організувати поставки і транспортні перевезення.

Функція організації полягає у формуванні організаційної структури управління підприємством, розподілі повноважень серед персоналу, забезпеченні підприємства засобами для досягнення поставлених завдань та організації виробничого процесу на підприємстві. Організаційна структура підприємства зазнає істотних змін при переході на аутсорсинг: зменшується штат працівників, змінюється внутрішньофірмова організація виробничогосподарських процесів, відбувається перерозподіл функцій, прав та відповідальності, порушуються принципи управління, змінюються способи і технологія ухвалення управлінських рішень, зазнає змін характер підпорядкованості між рівнями і ланками підприємства тощо. Цю функцію управління допомагає виконати аутсорсинг управління персоналом, рекрутмент, облік кадрів та кадровий супровід, виробничий аутсорсинг та ресурсне 
забезпечення виробничих процесів. Передаючи аутсорсеру бізнес-процеси, підприємство планує оптимізувати організаційну структуру, упорядкувати організаційні процеси на підприємстві, удосконалити виробничий процес, підвищити якість продукції, досягати конкурентних переваг та позбутися нерентабельних частин виробництва.

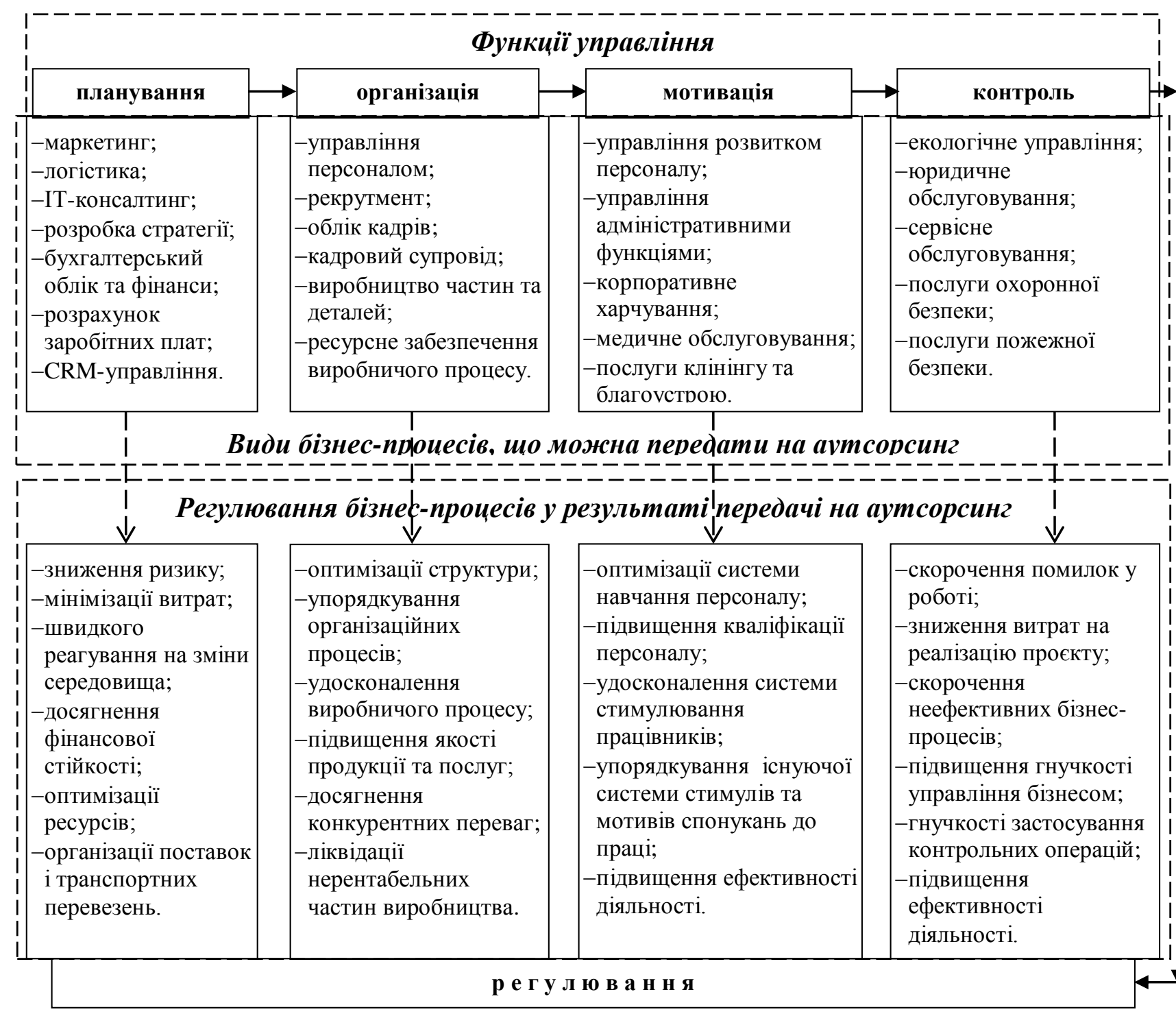

Рис. 2. Види аутсорсингу в системі функцій управління підприємством

Джерело: розроблено автором

Мотивація на підприємстві охоплює розробку і використання стимулів для ефективної взаємодії персоналу та переслідує мету активізувати персонал, спонукати його виконувати роботу більш ефективно, стимулювати морально та створити на виробництві умови для розвитку творчого потенціалу робітників. Функцію мотивації допомагає виконати аутсорсинг управління розвитком персоналу, адміністративних функцій, корпоративного харчування, управління інтелектуальними ресурсами, клінінгу та благоустрою, медичного 
обслуговування. Передаючи на аутсорсинг ці бізнес-процеси, підприємство планує оптимізувати систему навчання персоналу та підвищення його кваліфікації, удосконалити систему стимулювання працівників підприємства, упорядкувати систему стимулів та мотивів спонукань до праці.

Контроль в управлінні дозволяє забезпечити досягнення поставлених завдань, спостерігати, як підприємство рухається до поставленої мети та коригувати відхилення від прийнятого курсу в разі необхідності. Функція контролю включає облік і аналіз інформації про фактичні результати діяльності всіх підрозділів підприємства, порівняння їх із плановими показниками, виявлення відхилень і аналіз їхніх причин, розробку заходів щодо досягнення поставленої мети.

Контроль як функція управління успішно виконується при застосуванні аутсорсингу охоронної безпеки, пожежної безпеки, юридичного обслуговування, сервісного обслуговування та екологічного аутсорсингу. Передаючи на аутсорсинг визначені бізнес-процеси, підприємство планує скоротити кількість помилок у роботі, знизити витрати на реалізацію аутсорсингового проєкту, підвищити ефективність діяльності, скоротити неефективні бізнес-процеси, підвищити гнучкість управління бізнесом, забезпечити своєчасність, мобільність, надійність та гнучкість застосування контрольних операцій.

Важливою функцією при здійсненні аутсорсингу є регулювання. Вона полягає у спрямуванні діяльності на усунення відхилень, збоїв та недоліків, на досягнення узгодженості роботи всіх структурних підрозділів підприємства та на узгодженість між ними шляхом розроблення і впровадження відповідних заходів. Для реалізації цісї функції використовуються наради, збори, звіти, інтерв'ю, комп'ютерний зв'язок, засоби радіомовлення і телебачення. У цьому випадку відбуваються бізнес-процеси, пов'язані із систематизацією та обробкою інформації у процесі коригування та впровадження розроблених заходів. Тому можливе застосування аутсорсингу IT-послуг, які спрямовані на вдосконалення способів зв'язку та впровадження розроблених програм. Можливе також застосування трансформаційного аутсорсингу, що передбачає реорганізацію діяльності та створення нової бази навичок та нового продукту. Передаючи на аутсорсинг визначені бізнес-процеси, підприємство планує досягти узгодженості діяльності відповідно встановлених цілей, злагодженості в роботі всіх частин організації шляхом створення раціональних зв'язків між ними.

Реалізація зазначених функцій управління може розглядатися як ланцюжок, що починається з встановлення або планування цілей і закінчується контролем. Залежно від характеру відхилень чи недоліків, що були виявлені в процесі контролю у керованій системі, регулювання може скеровуватись на конкретний блок. Запропонована нами класифікація показує різноманітність реалізованих функцій управління при використанні аутсорсингу (рис. 2).

Розвиток кожної з функцій управління відбувається не тільки під впливом внутрішніх закономірностей їхнього удосконалення, але і під впливом розвитку інших функцій. Кожна 3 функцій повинна удосконалюватися в напрямі, який 
зумовлюється загальними цілями i завданнями розвитку підприємства в конкретних умовах.

Висновки. Сьогодні вважають, що аутсорсинг бізнес-процесів може бути частиною антикризової програми підприємств, оскільки багато підприємств мають велику кількість працівників і в період кризи починають скорочувати витрати на персонал. Тому, досить важливим є вибір видів бізнес-процесів у системі функцій управління, які необхідно передати на аутсорсинг. Такий вибір багато в чому залежить від переслідуваних цілей, від обраної функції управління, яку підприємство планує реалізувати, передаючи виконання робіт аутсорсеру. Тому варто продовжувати дослідження вагомості використання того чи іншого виду аутсорсингу в системі функцій управління.

\section{Список використаних джерел}

1. McIvor R. A practical framework for understanding the outsourcing process. Supply Chain Management: An International Journal. 2000. № 1. P. 22-36.

2. Mommea J., Hvolbyb H. An outsourcing framework: action research in the heavy industry sector. European Journal of Purchasing \& Supply Management. 2002. № 8. Pp. 185-196.

3. Тропіцина Ю. С. Апарат контролю аутсорсингу як головний орган менеджменту у процесі надання аутсорсингових послуг. Міжнародний наукововиробничий журнал. 2015. № 3. С. 251-260.

4. Тонюк М. О. Аутсорсинг як інструмент забезпечення ефективної діяльності підприємства. Економіка і суспільство. 2017. № 10. С. 372-376.

5. Попова А. Ю. Нові тенденції в управлінні потенціалом підприємств на підставі реінжинірингу бізнес-процесів та аутсорсингу. Економіка промисловості. 2009. № 3. С. 158-162.

6. Бабій М. А. Аутсорсинг як нова концепція ведення бізнесу. Зовнішня торгівля: право та економіка. 2007. № 6. С. 53-57.

7. Висоцький В. В. Аутсорсинг як технологія менеджменту інформаційної безпеки підприємства. Вісник Хмельницьького національного університету. 2010. № 2. С. 62-64.

8. Сухоняк С. О. Формування стратегічних альтернатив розвитку аутсорсингової діяльності підприємств. Науковий вісник НЛТУ Украӥни. 2017. № 2. C. $76-80$.

9. Лабжанія Р. Г. Місце і роль аутсорсингу в сфері послуг і виробництві. Бізнес Інформ. 2013. № 7. С. 357-360.

10. Новохатній А. А. Навіщо потрібен аутсорсинг бізнес-процесів. URL: https://mind.ua/openmind/20177545-navishcho-potriben-autsorsing-biznes-procesiv (дата звернення 20.03.2020).

11. Васильченко Г. В. Аутсорсинг як елемент взаємозв'язку між суб' єктами господарювання реального та фінансового секторів економіки. URL: http://fkd.org.ua/article/view/28975 (дата звернення 28.03.2020). 


\section{References}

1. McIvor, R. (2000). A practical framework for understanding the outsourcing process. Supply Chain Management: An International Journal, 1, 22-36 [in England].

2. Mommea, J. \& Hvolbyb, H. (2002). An outsourcing framework: action research in the heavy industry sector. European Journal of Purchasing \& Supply Management, 8, 185-196 [in Netherlands].

3. Tropitsyna, Yu. S. (2015). Aparat kontrolyu autsorsynhu yak holovnyy orhan menedzhmentu u protsesi nadannya aut sorsynhovykh posluh [The outsourcing control apparatus as the main management body in the process of providing outsourcing services]. Mizhnarodnyy naukovo-vyrobnychyy zhurnal - International research and production journal, 3, 251-260 [in Ukrainian].

4. Tonyuk, M. O. (2017). Autsorsynh yak instrument zabezpechennya efektyvnoyi diyalnosti pidpryyemstva [Outsourcing as a tool to ensure the effective Ukrainian].

6. Babiy, M. A. (2007). Autsorsynh yak nova kontseptsiya vedennya biznesu [Outsourcing as a new concept of doing business]. Zovnishnya torhivlya: pravo ta ekonomika - Foreign trade: law and economics, 6, 53-57 [in Ukrainian].

7. Vysotskyy, V. V. (2010). Autsorsynh yak tekhnolohiya menedzhmentu informatsiynoyi bezpeky pidpryyemstva [Outsourcing as a technology of information security management of the enterprise]. Visnyk Khmelnytskoho natsionalnoho universytetu - Visnyk of Khmelnytsky National University, 2, 62-64. [in Ukrainian].

8. Sukhonyak, S. O. (2017). Formuvannya stratehichnykh alternatyv rozvytku autsorsynhovoyi diyalnosti pidpryyemstv [Formation of strategic alternatives for the development of outsourcing activities of enterprises]. Naukovyy visnyk NLTU Ukrayiny - Scientific Bulletin of NLTU of Ukraine, 2, 76-80 [in Ukrainian].

9. Labzhania, R.G. (2013). Mistse i rol aytsorsungy v sferi poslyg i vurubnutstvi [The place and the role of outsourcing in the field of services and production]. Biznes Inform - Business Inform, 7, 357-360 [in Ukrainian].

10. Novokhatniy, A. A. (2009). Navishcho potriben autsorsynh biznesprotsesiv [Why outsource business processes]. (n.d.). https://mind.ua/ Retrieved from https://mind.ua/openmind/20177545-navishcho-potriben-autsorsing-biznes-procesiv [in Ukrainian].

11. Vasylchenko, H.V. (2011). Autsorsynh yak element vzayemozvyazku mizh subyektamy hospodaryuvannya realnoho ta finansovoho sektoriv ekonomiky [Outsourcing as an element of the relationship between economic entities of the real 
and financial sectors of the economy]. (n.d.). http://fkd.org.ual Retrieved from http://fkd.org.ua/article/view/28975 [in Ukrainian].

\section{Відомості про авторів}

ДАНИЛЮК Тетяна Іллівна - кандидат економічних наук, доцент кафедри економіки, безпеки та інноваційної діяльності підприємства, Східноєвропейський національний університет ім. Лесі Українки (м. Луцьк).

МОХНЮК Анна Миколаївна - кандидат економічних наук, доцент кафедри економіки, безпеки та інноваційної діяльності підприємства, Східноєвропейський національний університет ім. Лесі Українки (м. Луцьк).

DANYLIUK Tetiana, $\mathrm{PhD}$ in Economics, Associate Professor, Department of Economics, Security and Innovation of the Enterprise, Lesya Ukrainka Eastern European National University (Lutsk).

MOKHNIUK Anna, PhD in Economics, Associate Professor, Department of Economics, Security and Innovation of the Enterprise, Lesya Ukrainka Eastern European National University (Lutsk).

ДАНИЛЮК Татьяна Ільинична - кандидат экономических наук, доцент кафедры экономики, безопасности и инновационной деятельности предприятия, Восточноевропейский национальный университет им. Леси Украинки (г. Луцк).

МОХНЮК Анна Николаевна - кандидат экономических наук, доцент кафедры экономики, безопасности и инновационной деятельности предприятия Восточноевропейский национальный университет им. Леси Украинки (г. Луцк).

УДК: 339.14:663.64

DOI: $10.37128 / 2411-4413-2020-2-8$

ФАКТОРНI

ДЕТЕРМІНАНТИ

СПОЖИВЧОГО ПОПИТУ

МІНЕРАЛЬНОЇ ВОДИ
ФАЙВІШЕНКО Д. С., кандидат економічних наук, доцент кафедри журналістики та реклами, Київський національний торговельноекономічний університет (м. Kиїв)

В умовах функціонування підприємств в активному середовищі з високою конкуренцією, дослідження факторних детермінант споживчого вибору $\epsilon$ ключовим завданням для формування стратегії розвитку та управління брендом. Саме формування концепиії стратегічного управління робить акцент на центральну роль факторів щодо прийняття основних рімень, синтезу конщепції позиціонування бренду та його иіннісних атрибутів, иілеспрямованого впливу на свідомість споживача $і$ зумовлює його попит загалом. Аналіз факторних детермінант споживчого вибору брендів на ринку мінеральної води, обтрунтування процесу ухвалення рімень стає сьогодні досить актуальним. Методи дослідження базуються на теоретико-методичних аспектах аналізу факторів споживчого попиту та вибору брендів мінеральної води, аналітичних даних стану ринку та споживання 